\title{
The influence of baking duration on the sensory quality and the nutrient content of mung bean biscuits
}

\author{
*Setyaningsih, D.N., Fathonah, S., Putri, R.D.A, Auda, A.K. and Solekah, N. \\ Faculty of Engineering, Universitas Negeri Semarang, Sekaran, Gunungpati, Semarang, Indonesia
}

\begin{abstract}
Article history:
Received: 19 February 2019

Received in revised form: 7

April 2019

Accepted: 3 June 2019

Available Online: 19 June

2019
\end{abstract}

\section{Keywords:}

Baking duration,

Sensory quality,

Nutrition,

Biscuit,

Mung bean

DOI:

https://doi.org/10.26656/fr.2017.3(6).089

\begin{abstract}
Baking is one of the cooking stages to determine the form, taste, and the color of biscuit. The purpose of this study was to determine the effects of different baking times on the sensory quality and nutrient content of mung bean biscuit. This research was designed using an application approach. Mung bean biscuit made from 60\% mung bean flour, $20 \%$ wheat flour, and $20 \%$ cornstarch were baked at different baking times, i.e. 13, 15, 17, 19, and $21 \mathrm{mins}$, at $150^{\circ} \mathrm{C}$. A total of ten trained panelist were asked to participate in the sensory testing using the scoring method. In addition, the mung bean biscuits were subjected to proximate analysis; energy content using the calorimeter; carbohydrate content using the Luff School method; protein content using the micro Kjeldahl method; fat content using the Soxhlet method; and fiber content was using the gravimetric method. The iron content of the mung bean biscuit was also tested using the colorimetric method. Data were analyzed with ANOVA followed by the Duncan test. It was observed that the baking times influenced the sensory attributes of the biscuit in terms of the color, aroma, and texture. The mung bean biscuits baked at $17 \mathrm{mins}$ had the best overall sensory attributes with overall acceptance of 7.2 (maximum score $=9$ ) with a sweet taste (score 7.0) and original mung bean flavor (score 6.7). Mung bean biscuits baked for 13 - 21 mins contained 445 - $454 \mathrm{kcal}$ energy, carbohydrate content $62.57-65.02 \%$, protein content $7.57-8.04 \%$, fat content $17.94-19.15 \%$, moisture content $5.11-6.75 \%$, ash content 0.95 - $1.74 \%$, and fiber content $1.50-2.75 \%$. The iron content of the mung bean biscuit was also very high at $17.53-26.37 \mathrm{mg}$.
\end{abstract}

\section{Introduction}

Biscuit is a product made from soft flour with low protein content (Sumnu and Sahin, 2008). According to BSN (2011), the biscuit is made by baking dough from flour with or without substitution, oil/fat, with or without the addition of other food ingredients and allowed food additives. Biscuit made from a mixture of soy flour or cassava flour will increase the protein and calories (Akubor and Ukwuru, 2003). It is suitable for children food program. The research of Fathonah (2015) resulted in the Mung bean biscuit with 35\% margarine which has $453 \mathrm{kcal}$ energy, $11.3 \%$ protein, and $13.1 \%$ fiber. Moreover, it is acceptable and liked (Fathonah and Muvida, 2015). In order to have a better quality biscuit, further research is needed on optimum baking time.

Baking is a biscuit cooking process. Biscuits are baked in a hot temperature oven to determine the shape, taste, and color. The use of different materials requires a different baking length and temperature, usually around $180-200^{\circ}$ C. Several studies on baking biscuit used different temperature and baking duration. Some examples include biscuit made from the mixture of rice flour, akra, and sesame baked at a temperature of $200^{\circ} \mathrm{C}$ for 15 mins (Nnam et al., 2003); milk powder biscuits baked at $250^{\circ} \mathrm{C}$ (top heat) $/ 230^{\circ} \mathrm{C}$ (bottom heat) for 12 mins (Gallagher et al., 2005); Anethole flavor biscuit baked in a travel oven (zone 1: $215^{\circ} \mathrm{C}$, zone $2: 175^{\circ} \mathrm{C}$, zone 3: $195^{\circ} \mathrm{C}$ ) for 8 mins (Burseg et al., 2009); cassava biscuits baked at $160^{\circ} \mathrm{C}$ for 30 mins (Obadina et al., 2014); bamboo shoots powder biscuit baked at $160^{\circ} \mathrm{C}$ for 20 mins (Choudhury et al., 2015); and biscuits made with the mixture of spirulina flour, guar gum, orghum flour, and wheat flour baked at $170^{\circ} \mathrm{C}$ for 25 minutes (Singh et al., 2015); and biscuits made with 50\% corn floour, $40 \%$ wheat flour and $10 \%$ cornstarch baked at $170^{\circ} \mathrm{C}$ for 15 mins (Fathonah et al., 2018).

Hence, the purpose of this study was to determine the effects of baking time towards the sensory quality and nutrient content of mung bean biscuit. 


\section{Materials and methods}

\subsection{Biscuit making process}

For this study, the mung bean biscuit was made with the composition of $60 \%$ mung bean flour, $20 \%$ flour and $20 \%$ cornstarch. The materials used in the making of mung bean biscuits are shown in Table 1. Margarine was added with refined sugar and mixed for about 5 mins. Then, egg yolks were added and mixed for 2 mins. After that, mung bean flour, wheat flour, cornstarch, and baking powder were added and mixed until smooth for 1 minute. The dough was rolled to a thickness of $3 \mathrm{~mm}$ and molded, each at a weight of $6 \mathrm{~g}$. The dough molds were arranged on a baking sheet and poked with small holes. The dough molds were baked at $150^{\circ} \mathrm{C}$ with different baking times, i.e. 13 mins ( $\left.\mathrm{P} 13^{\prime}\right), 15$ mins (P 15'), 17 mins (P17'), 19 mins (P 19'), and 21 mins (P 21'). The baking pan was rotated every 5 minutes to get the same heat. Baked mung bean biscuits were then cooled for 5 minutes.

Table 1. Materials of mung bean biscuit

\begin{tabular}{lc}
\hline \multicolumn{1}{c}{ Material } & Weight $(\mathrm{g})$ \\
\hline Mung bean flour & 180 \\
Wheat flour & 60 \\
Cornstarch flour & 60 \\
Margarine & 125 \\
Refined sugar & 125 \\
Liquid milk & 30 \\
Egg white & 20 \\
Baking powder & 3 \\
\hline
\end{tabular}

\subsection{Sensory analysis}

Sensory analysis was conducted with the scoring method using a 9-point quality scale following the standard procedures (Meilgaard et al., 2007). A total of ten trained panelists (age between 40 to 60 years old women) were invited to perform the sensory analysis. The mung bean biscuits were coded and presented to the panelists. Panelists were asked to score the samples based on the quality aspects (color, aroma, crispiness, sweetness, mung bean flavor and overall quality) from 1 to 9 , where 1 represent the biscuit at very low quality and 9 represent the biscuit at very high quality, with the details: color: $1=$ very light color, $9=$ very dark color; Aroma: $=$ extremely not fragrant, $9=$ very fragrant; crispiness : $1=$ not crispy, $9=$ extremely crispy; sweetness: 1 = extremely not sweet, $9=$ extremely sweet; mung bean flour: 1 = weak flavor intensity, $9=$ strong flavor intensity; and overall: $1=$ very low quality, $9=$ very high quality. Drinking water was prepared for panelists and they were asked to rinse after tasting the biscuit. The sensory analysis was performed three times with a delay of 30 mins in between.

\subsection{Chemical analysis}

Among the chemical analysis performed on the mung bean biscuits include energy content analyzed using the calorimetric method; carbohydrate using the Lurf School method; protein content using the micro Kjeldahl method; fat content using the Soxhlet method; fiber content using the gravimetric method; and iron content using the colorimetric method (AOAC, 1995).

\subsection{Data analysis technique}

ANOVA was used to analyze the effects of different baking times on the sensory quality of mung bean biscuit. The difference between treatments was continued with the Duncan test. The significant level was established at $p<0.05$ (Kadir, 2015).

\section{Results}

Table 2 tabulates the sensory quality analysis of the mung bean biscuits baked at different baking times. Overall, mung bean biscuits baked for 17 mins had the best score (7.2) followed by 21 mins (7.0), 19 mins (6.8), 15 mins (6.6) and 13 mins (6.4). The scores were statistically insignificant. Based on the color of the biscuits, biscuits baked for 21 mins obtained the highest score for color (5.4) with the highest intensity of the golden yellow color (Figure 1) and significantly different from other baking times. The different baking times influenced the color of the biscuits greatly. A good quality biscuit is indicated by the yellow color of the biscuit. As shown in Figure 1, the golden yellow intensity increases as the baking time increases; 13 mins were pale golden yellow while 21 mins were brown.

Table 2. The result of sensory evaluation of mung bean biscuits with different baking times

\begin{tabular}{lccccc}
\hline \multicolumn{1}{c}{ Quality Attribute } & P 13' & P 15' & P 17' & P 19' & P 21 \\
\hline Color & $2.3^{\mathrm{a}}$ & $3.0^{\mathrm{a}}$ & $3.4^{\mathrm{b}}$ & $3.9^{\mathrm{b}}$ & $\mathbf{5 . 4}^{\mathrm{c}}$ \\
Aroma & $5.6^{\mathrm{a}}$ & $6.1^{\mathrm{a}}$ & $6.6^{\mathrm{b}}$ & $6.6^{\mathrm{b}}$ & $\mathbf{6 . 7}^{\mathbf{b}}$ \\
Crispiness & $6.5^{\mathrm{a}}$ & $6.9^{\mathrm{a}}$ & $7.4^{\mathrm{b}}$ & $7.1^{\mathrm{a}}$ & $\mathbf{7 . 5}^{\mathrm{b}}$ \\
Sweetness & $6.3^{\mathrm{a}}$ & $6.7^{\mathrm{a}}$ & $\mathbf{7 . 0}^{\mathrm{a}}$ & $6.9^{\mathrm{a}}$ & $6.9^{\mathrm{a}}$ \\
Mung bean flavor & $6.7^{\mathrm{a}}$ & $6.7^{\mathrm{a}}$ & $6.7^{\mathrm{a}}$ & $6.7^{\mathrm{a}}$ & $\mathbf{6 . 8}^{\mathrm{a}}$ \\
Overall & $6.4^{\mathrm{a}}$ & $6.6^{\mathrm{a}}$ & $\mathbf{7 . 2}^{\mathrm{a}}$ & $6.8^{\mathrm{a}}$ & $7.0^{\mathrm{a}}$ \\
\hline
\end{tabular}

Different alphabet superscripts in the same row indicates significant difference.

Biscuits baked for $21 \mathrm{mins}$ had the highest score for aroma (6.7), crispiness (7.5) and mung bean flavor (6.8). The score for aroma was significantly different from biscuits baked for 13 and 15 mins while the score for crispiness was significantly different from biscuits baked for 13, 15 and 19 mins. No significant difference was observed for the scores of mung bean flavor similar to the sweetness of the biscuits. The sweetness of the 

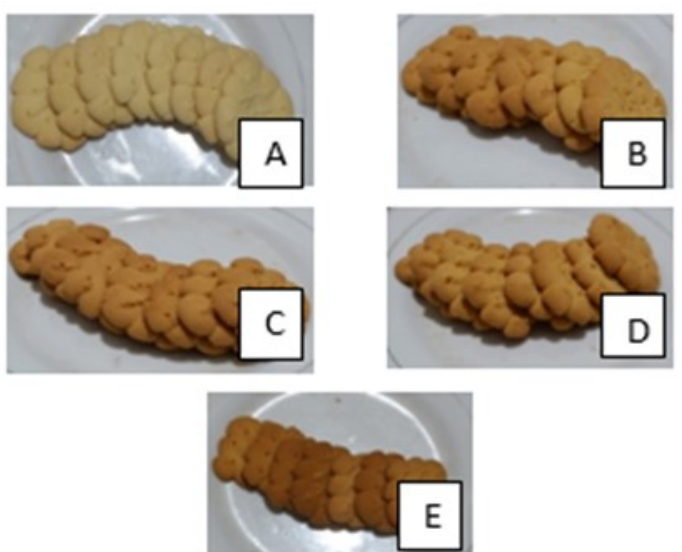

Figure 1. Mung bean biscuits of different baking times. A. 13 mins; B. 15 mins; C. 17 mins; D. 19 mins; and E. 21 mins

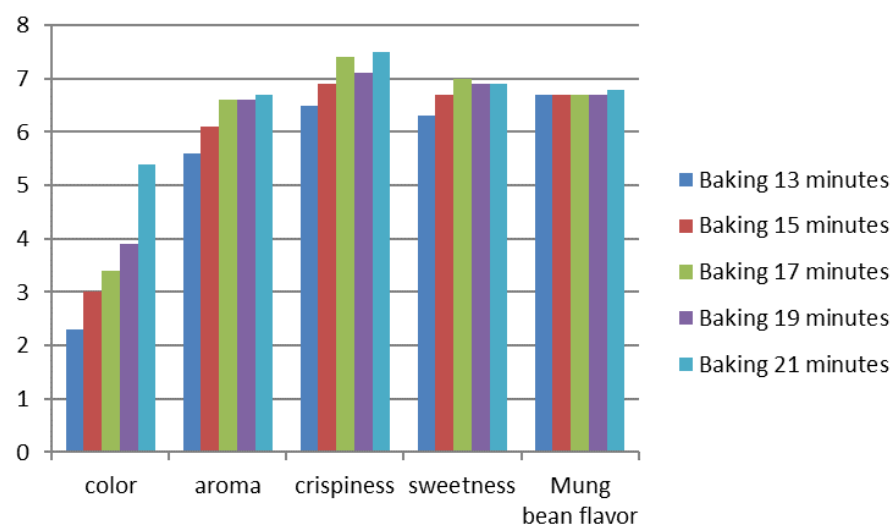

Figure 2. Sensory evaluation of the mung bean biscuits according to the baking times

Table 3. The nutrient content of mung bean flour and mung bean biscuit based on the baking time

\begin{tabular}{|c|c|c|c|c|c|c|c|c|}
\hline $\begin{array}{l}\text { Baking time } \\
\text { (minutes) }\end{array}$ & Water $(\%)$ & Ash (\%) & Protein $(\%)$ & Fat $(\%)$ & Crude Fiber $(\%)$ & Carbohydrates (\%) & Iron (mg) & Energy (kcal) \\
\hline Mung bean flour & 6.56 & 3.11 & 18.42 & 1.9 & 3.77 & 66.25 & 89.62 & 351 \\
\hline 13 & 6.75 & 0.95 & 7.57 & 18.22 & 1.5 & 65.02 & 17.53 & 448 \\
\hline 15 & 6.55 & 1.14 & 7.64 & 19.11 & 1.75 & 63.75 & 19.07 & 451 \\
\hline 17 & 5.52 & 1.29 & 7.95 & 19.1 & 1.94 & 64.22 & 19.75 & 454 \\
\hline 19 & 5.63 & 1.66 & 8.04 & 19.15 & 2.38 & 62.57 & 24.19 & 452 \\
\hline 21 & 5.11 & 1.74 & 7.83 & 17.94 & 2.75 & 64.64 & 26.37 & 445 \\
\hline SNI 2973:2011 & Max 5 & - & $\operatorname{Min} 5$ & - & - & - & - & - \\
\hline
\end{tabular}

biscuits ranged from 6.3 to 7.0 , with the highest score was from the biscuit baked for 17 mins (Figure 2).

The nutrient content of the mung bean flour and the mung bean biscuits baked for different baking times are tabulated in Table 3. The mung bean flour was high in protein content $(18.42 \%)$, iron content $(89.62 \mathrm{mg})$ and crude fiber content $(3.77 \%)$. All biscuits baked for different baking times had water contents of more than $5 \%$, exceeding the requirement of SNI standard (SNI 2973: 2011). Biscuits baked for 13 mins had the highest water content $(6.75 \%)$ while the lowest water content (5.11\%) was biscuits baked for 21 mins. However, the protein content of the biscuits met the requirement of SNI standard whereby all biscuits had more than $5 \%$ protein content. A similar increasing trend following the baking times was observed in the ash content, crude fiber content and iron content. Biscuits baked for $21 \mathrm{mins}$ observed a drop in the protein and fat content after a gradual increasing trend as the baking time increases.

\section{Discussion}

Various lengths of baking duration produced different qualities of mung bean biscuit, especially on the sensory qualities. The longer baking duration, the darker the color of mung bean biscuit. It was due to the Maillard reaction, the reaction between the sugar redactor with the limited amino group of amino acids or proteins. The Maillard reaction produces the brown color and a distinctive aroma. Baking in high temperatures and long duration will cause lower water content and darker color in the biscuit (Manley, 2000). In the baking process, the taste substances are formed, including caramelization of the sugar, pyrodextrin, and melanoidin. It produces a product that has the required and different sensory characteristics (Desrosier, 1988). The similar result of a baking carob indicates that the browning index of the baked carob increases with the increasing baking temperature and time. All the chemical characteristics of carob powder was significant $(\mathrm{P}<0.0001)$ during the baking duration in 20 - 60 mins (Şahin et al., 2009). Baking duration also has a significant effect on the color of the cake crust made from the wheat flour (Bilgen et al., 2007).

There were differences in the aroma of mung bean biscuit based on the baking duration. A stronger aroma was perceived for a longer duration. The aroma of food can be influenced by the ingredients used in the cooking process. The ingredients used will react during the baking process and produce aromas in the biscuit. The aroma of biscuit comes from the evaporation of volatile compounds and the reaction between the used ingredients; sugar, margarine and baking powder. A total of 69 volatile compounds were identified in a baked bean, such as pyrazines and furan (Jiao et al., 2016).

The difference in of crispiness of mung bean biscuit was because of the different length of baking. The longer 
baking duration caused more evaporation of the water and fat. The lower water content made a crunchier biscuit. Water is an essential component in the food ingredients since it gives an effect to the appearance, texture, and taste of food (Winarno, 2002). The crispiness of the biscuit was also supported by the small water content and the longer duration of baking. The water content of the biscuits baked for 13 mins was $6.7 \%$ while biscuits baked for 21 mins was $5.11 \%$. It was compatible with the characteristics of biscuit which have low water (Sumnu and Sahin, 2008). According to Lean (2013), biscuit has a water content around 3\%. SNI 2973: 2011 (BSN, 2011) requires a maximum water content of $5 \%$. A decrease in the water content, the fat and protein content were also affected for biscuits baked for 21 mins.

The primary sensory quality of the biscuit is the crispiness. Crispy is the noise and strength when the sample of biscuit breaks or cracks chewed on the first and second (Meilgaard et al., 2007). The result shows that the baking duration made a clear difference to the crispiness of biscuits; longer baking duration made higher crispiness. In the baking process, there was evaporation of the dough water and the surface of the biscuit. This process was followed by the transfer of moisture to the surface then continuously lost to the oven. It decreased the water content and made a crunchy texture. If the water level is too low, the biscuit surface becomes overcooked, or the color is too dark and burnt (Manley, 2000) like the biscuits baked for $21 \mathrm{mins}$ (Figure 1E).

For the overall sensory analysis, the best result was the biscuits baked for 17 mins with a score of 7.2. It shows that the baking process played a role in producing required changes; taste, color, and aroma of the biscuit (Lean, 2013). This result is almost the same with research on biscuit made from $59.65 \%$ sugar, $46.68 \%$ fat, and $14 \%$ water. With the temperature of $190^{\circ} \mathrm{C}$ and 16 mins $30 \mathrm{~s}$ baking, the best biscuit was produced (Panghal et al., 2018). The biscuit of $6 \%$ sweet potato, red beans $(10 \%)$, and flour $(30 \%)$ require a longer baking time of 25 mins at $150^{\circ} \mathrm{C}$ (Mayasari et al., 2015).

The results on the analysis of the energy, carbohydrate, protein, and fat content of the mung bean biscuit are quite high. It showed the increase of the protein along with the longer baking time. Desrosier (1988) stated that during the baking process, food loses water content which causes an increase of nutrient content in the left mass. The amount of protein and carbohydrates per unit weight in dry food ingredients is higher than the fresh ingredients. It causes energy, carbohydrate, protein, and fat content to increase over a long period of different baking processes. Biscuit with a composition of $70 \%$ wheat, $20 \%$ soybeans, $10 \%$ rice bran has the following nutritional content; protein content (16.28 $\pm 0.41 \%)$; fiber content $(1.90 \pm 0.17 \%)$; and fat content $(12.13 \pm 0.67 \%)$ (Bunde et al., 2010). The baking process of biscuits with millet flour and legumes results in significantly higher protein for the utilization of the body, thus becoming a good source of protein (Geervani et al., 1996).

Furthermore, it is said that the fat heated at high temperatures will break down and form the acrolein which has an unpleasant color. The baking process also affects carbohydrate. Starch is converted into pyrodextrin which has a brown color and gives color to the crust. Sucrose is converted into dark caramel in complex compound reactions (Lean, 2013). Furthermore, the quality of biscuit is decreased because the starch content was decayed (Barrera et al., 2007).

To improve the quality of the biscuit, it is recommended to reduce the pressure during the baking process. The research conducted by Anese et al. (2016) in the in high temperature and pressure reduced baking process allowed to get biscuits with acceptable color and water content. It also minimized the oxidation of omega3 fatty acids, acrylamide and furan formation. Satisfactory sensory and nutritional biscuits were produced by applying a combination of $174^{\circ} \mathrm{C}$, a pressure of $3.99 \mathrm{kPa}$ for 45 minutes (Anese et al., 2016).

The crude fiber content was quite high, around 1.50 $2.57 \%$. High fiber content will reduce the crispiness of the biscuits with darker color due to the fiber is cellulose from the walls of plants that have a solid structure (Andarwulan et al., 2011).

The findings of the iron content of the mung bean biscuit were $17.53-26.37 \mathrm{mg}$. The high iron content indicates that $60 \%$ mung bean biscuit is useful as a source of iron which is higher than $2.7 \mathrm{mg}$ flour biscuit, $4.9 \mathrm{mg}$ fried tempeh, $0.9 \mathrm{mg}$ fried fish, $3.0 \mathrm{mg}$ fried coated peanuts, and $4.0 \mathrm{mg}$ fried peanuts. The biscuits with a high iron content can be used as an alternative snack to overcome iron deficiency or anemia which is experienced by many toddlers, school children, the elderly, pregnant women, and nursing mothers. According to Fathonah (2016), iron deficiency in pregnant women can increase the risk of death during childbirth, babies born with iron deficiency and adversely affecting children's brain cell growth. In adults, iron deficiency can reduce work productivity by $20-30 \%$. 


\section{Conclusion}

The best overall sensory quality biscuit of $60 \%$ mung bean flour, $20 \%$ wheat flour, and $20 \%$ cornstarch flour was baked for 17 mins with a score of 7.2. The duration of the baking process made a real difference in the color, aroma, and crispiness. The increasing baking time decreased the water content. However, the ash, crude fiber, and iron content increased. The protein and fat content showed a drop in the biscuits baked for 21 min after a gradual increase for biscuits baked for 13 to 17 mins. The biscuit can be an alternative snack in providing high protein and iron content.

\section{References}

Akubor, P.I. and Ukwuru, M.U. (2003). Functional properties and biscuit making potential of soybean and cassava flour blends. Plant Foods for Human Nutrition, 58(3), 1-12. https://doi.org/10.1023/ B:QUAL.0000040344.93438.df

Andarwulan, N., Feri, K. and Dian, H. (2011). Analisis Pangan. Jakarta: PT. Dian Rakyat. [In Bahasa Indonesia].

Anese, M., Valoppi, F., Calligaris, S., Lagazio, C., Suman, M., Manzocco, L. and Nicoli, M.C. (2016). Omega-3 enriched biscuits with low levels of heatinduced toxicants: Effect of formulation and baking conditions. Food and Bioprocess Technology, 9(2), 232-242. https://doi.org/10.1007/s1 1947-015-1613 $-\mathrm{x}$

AOAC (Association of Analytical Chemists). (1995). Official Methods of Analysis. Washington, D.C.: AOAC

BSN (Badan Standardisasi Nasional). (2011). SNI 2973: 2011 Biskuit. Jakarta: Badan Standardisasi Nasional. [In Bahasa Indonesia].

Barrera, G.N., Pérez, G.T., Ribotta, P.D. and León, A.E. (2007). Influence of damaged starch on cookie and bread-making quality. European Food Research and Technology, 225(1), 1-7. https://doi.org/10.1007/ s00217-006-0374-1

Bilgen, S., Coşkuner, Y. and Karababa, E. (2004). Effects of baking parameters on the white layer cake quality by combined use of conventional and microwave ovens. Journal of Food Processing and Preservation, 28(2), 89-102. https://doi.org/10.1111/ j.1745-4549.2004.tb00813.x

Bunde, M.C., Osundahunsi, F.O. and Akinoso, R. (2010). Supplementation of biscuit using rice bran and soybean flour. African Journal of Food, Agriculture, Nutrition and Development, 10(9), 4047 -4059. https://doi.org/10.4314/ajfand.v10i9.62887

Burseg, K., Linforth, R.S., Hort, J. and Taylor, A.J.
(2009). Flavor perception in biscuits; correlating sensory properties with composition, aroma release, and texture. Chemosensory Perception, 2(2), 70-78. https://doi.org/10.1007/s12078-009-9042-8

Choudhury, M., Badwaik, L.S., Borah, P.K., Sit, N. and Deka, S.C. (2015). Influence of bamboo shoot powder fortification on physico-chemical, textural and organoleptic characteristics of biscuits. Journal of Food Science and Technology, 52(10), 6742-6748. https://doi.org/10.1007/s13197-015-1709-3

Desrosier, N.W. (1988). Teknologi pengawetan Makanan. Jakarta: UI Press. [In Bahasa Indonesia].

Fathonah, S. and Muvida, F. (2015). Mung Bean Biscuits for Early Childhood, presented at $1^{\text {st }}$ UNNES International Conference on Research Innovation and Commercialization for the Better Life, Semarang, 2015. Semarang: LP2M UNNES.

Fathonah, S. (2016). Gizidan Kesehatan untuk Ibu hamil. Kajian Teoridan Aplikasinya. Jakarta: Erlangga.[In Bahasa Indonesia].

Fathonah, S., Rosidah, R. and Septianarta, S. (2018). Yellow Corn Biscuits for Early Childhood: High Energy and Beta-carotene. Jurnal Bahan Alam Terbarukan, 7(1), 77-82. https://doi.org/10.15294/ jbat.v7i1.9723

Gallagher, E., Kenny, S. and Arendt, E.K. (2005). Impact of dairy protein powders on biscuit quality. European Food Research and Technology, 221(3-4), 237-243. https:// doi.org/10.1007/s00217-005-1140-5

Geervani, P., Vimala, V., Pradeep, K.U. and Devi, M.R. (1996). Effect of processing on protein digestibility, biological value and net protein utilization of millet and legume based infant mixes and biscuits. Plant Foods for Human Nutrition, 49(3), 221-227. https:// doi.org/10.1007/BF01093218

Jiao, S., Zhu, D., Deng, Y. and Zhao, Y. (2016). Effects of hot air-assisted radio frequency heating on quality and shelf-life of roasted peanuts. Food and Bioprocess Technology, 9(2), 308-319. https:// doi.org/10.1007/s11947-015-1624-7

Kadir. (2015). Statistika Terapan. Jakarta: Raja Grafindo Persada. [In Bahasa Indonesia].

Lean, M.E. (2013). Ilmu Pangan, Gizidan Kesehatan (translated). Yogyakarta: Pustaka Pelajar. [In Bahasa Indonesia].

Meilgaard, M.C., Civille, G.V. and Carr, B.T. (2007). Sensory Evaluation Techniques. $2^{\text {nd }}$ ed. London: CRC Press, Inc. https://doi.org/10.1201/b16452

Manley, D. (2000). Technology of biscuits, crackers and cookies. USA: Woodhead Publishing Ltd. https:// doi.org/10.1201/NOE0849308956 
Mayasari, R., Ikrawan, Y. And Widiantara, T. (2015). Kajian Karakteristik Biskuit yang Dipengaruhi Perbandingan tepung Ubi Jalar dan Tepung Kacang Merah. Bandung: Teknologi Pangan Universitas Pasundan, BSc. Thesis. [In Bahasa Indonesia].

Nnam, N.M. and Nwokocha, M.O. (2003). Chemical and organoleptic evaluation of biscuits made from mixtures of hungry rice, acha (Digitaria exilis) sesame (Sesamum indicum) and breadfruit (Artocarpus atilis) flours. Plant Foods for Human Nutrition, 58(3), 1-11. https://doi.org/10.1023/ B:QUAL.0000040309.43301.64

Obadina, A.O., Oyewole, O.B. and Olaniyi, G. (2014). Effect of baking improvers on the quality of whole cassava biscuits. Journal of Food Science and Technology, 51(10), 2803-2808. https:// doi.org/10.1007/s13197-012-0732-x

Panghal, A., Chhikara, N. and Khatkar, B.S. (2018). Effect of processing parameters and principal ingredients on quality of sugar snap cookies: a response surface approach. Journal of Food Science and Technology, 55(8), 3127-3134. https:// doi.org/10.1007/s13197-018-3240-9

Şahin, H., Topuz, A., Pischetsrieder, M. and Özdemir, F. (2009). Effect of roasting process on phenolic, antioxidant and browning properties of carob powder. European Food Research and Technology, 230(1), 155. https://doi.org/10.1007/ s00217-009-1152-7

Singh, P., Singh, R., Jha, A., Rasane, P. and Gautam, A.K. (2015). Optimization of a process for high fibre and high protein biscuit. Journal of Food Science and Technology, 52(3), 1394-1403. https:// doi.org/10.1007/s13197-013-1139-z

Sumnu, S.G. and Sahin, S. (2008). Food engineering aspects of baking sweet goods. USA: CRC Press. https://doi.org/10.1201/9781420052770

Winarno, F.G. (2002). Kimia Pangan dan Gizi. Jakarta: PT Gramedia Pustaka Utama. [In Bahasa Indonesia]. 